\title{
The 'díszmagyar' as representation in the Andrássy family in late nineteenth-century Budapest
}

The aim of this chapter is to examine and contextualize the concept of luxury in a Hungarian aristocratic family in late nineteenth century Budapest and to investigate the ways and mechanisms in which luxury intersected with social representation. The chapter analyzes the festive outfits of the Count Andrássy family members, which were used as tools by the aristocracy in the construction of their self-image and in legitimizing their social position. The analysis is based on the Hungarian gala dress (so-called 'díszmagyar) and other festive garments which worked as costumes in their 'social theatre'. The paper examines the aristocracy's preference for the Hungarian gala dress or the European festive dress and sheds light on the questions of group identity and self-perception of the male and female aristocrats. The interconnectedness of the urban economy of Budapest, especially the tailors and dressmakers, and of the aristocratic consumption of luxury provides the framework for the analysis.

\section{The meaning of luxury for the aristocracy}

From the categories of luxury goods listed by Christopher J. Berry in The Idea of Luxury: A Conceptual and Historical Investigation, the paper examines clothing. ${ }^{1}$ Clothing has long been a means of communication with society, conveying symbolic values. Expensive, fine textiles, rare and exclusive jewellery are traditionally marks of luxury and status. As Berry argues, approaching luxury from a moralizing perspective does not give the best results since luxury is 'ineliminable'; it is the embodiment of both human desire and needs. He also points out that it is more fruitful to understand luxury in relational terms, because what is a necessity for one person or one social group might be a luxury for another. ${ }^{2}$ In this understanding the official garments, 
the 'díszmagyar' and the jewellery used by the Hungarian aristocracy, can be interpreted as a social necessity, since they were vital for communicating and maintaining their position in society. The question Berry asks is how does luxury and necessity bear more specifically on the rules which constitute social identity. One way of looking at luxury - in the present case the gala dress - as a tool for examining social identity is seeing it as a categorical continuity with a substantive discontinuity. ${ }^{3}$ The outfits in general are a timeless, continuous artefact, a tool for sending certain messages about one's position. However, the individual pieces of garment change over time, shaped by the contemporary structures of meaning. The 'díszmagyar' then becomes a representation of the self-perception of the Hungarian aristocracy and also a signifier of the social structures. ${ }^{4}$ It is especially interesting to see how the sign system of the 'díszmagyar' worked in the late nineteenth century urban setting, how the individual, personal aspirations surfaced or were suppressed by the concept of 'noblesse oblige'. In line with Maxine Berg and going back to Norbert Elias, focusing on the behaviour surrounding luxuries, rather than on the goods themselves, helps us interpret the mechanisms of the unfolding 'social drama. ${ }^{5}$ The Braudelian 'choice spectacle' unfolds with the help of the 'díszmagyar. ${ }^{6}$

In this analysis the focus is on three aspects: the 'díszmagyar' as a luxurious dress with added symbolic value based on the idea of historicism; the investigation of gender aspects by looking at the choices of male and female aristocrats; and finally the impact of the consumption practices of the aristocracy on the urban economy, more specifically the ways in which their choice for the special festive dress influenced the business of dressmaking and the formation of the 'magnate tailors.'

\section{Sources and methodology}

Because the activities of the members of the Hungarian aristocracy were acted out in public, there are numerous sources about their lives. Newspapers described their whereabouts in great detail, and the aristocracy often left behind personal notes in letters, diaries or memoirs. In the 
late nineteenth century, with the emergence of photography, the outfits, especially the ceremonial ones, were well documented, making research on clothes easier. In addition, there are account books and inventories. These sources combine to give a detailed picture of the relationship between luxury and representation of the aristocracy. However, this rich material has not been studied from the point of view of gender and luxury in the city. Thus, this chapter investigates, in the context of the rapid urban development of Budapest, the understanding of the notion of luxury through the example of one of the most important Hungarian aristocratic families in the nineteenth century.

The chapter builds on contemporary newspapers, fashion magazines, memoirs of aristocrats and foreign, mostly English accounts of their Hungarian experience. An additional layer of information to the present research is provided by the letters of Miss Mary Elizabeth Stevens, the family's English governess. ${ }^{7}$ She stayed in Hungary for five years (1864-1869) and wrote long and detailed letters to her family about her experiences in the Andrássy households. Her letters, as a source, are special in many ways in the context of luxury in the city and its connections to gender. In addition, her letters provide an English perspective of the anglophile Hungarian society. It is a well-known fact that the Hungarian aristocracy was often imitating the English, not only in terms of fashion, but also in terms of urban and social development. Next to Paris, London was the inspiration for the Hungarian modernizing metropolis. Mary had experience living in France and in England, having moved to France with her mother and sister after her father's early death. Because she was acquainted with both countries, she could compare not only the capital cities and their urban developments, but the social life as well. The comparative perspective Mary's letters bring is particularly pronounced for the private spheres of life especially clothing and daily family activities.

According to research, for most of the nineteenth century English travellers, Hungary fell largely in the realm of exotic. ${ }^{8}$ What is special about the letters of Miss Stevens, in comparison with other British accounts from travellers, is that she lived with the family, took part in various 
social activities, and used the infrastructure and services of the city for years. Her accounts add a more nuanced, gendered perspective to the already existing narrative about the role of luxury in shaping and representing social positions.

\section{Setting the scene: the urbanization of Buda-Pest}

The history of the Hungarian nation in the nineteenth century revolved around the struggle for independence from the Habsburg Monarchy. The aim was to achieve the same independence as in the Middle Ages. Because of this, an idealization and glorification of that historic period appeared in all spheres of cultural life. In 1867, when the Austro-Hungarian Compromise came about and Hungary again had a king and independent governance they used references to the past, which became a legitimizer for their achievements. In this way the medieval became the modern, and the aristocracy, a 'feudal' group became the facilitator of a modern institutional system. The two were not mutually exclusive; it was rather a peculiar continuity which manifested itself in their representative, festive garments as well. As Christopher Breward points out in The Culture of Fashion, one cannot argue against the unprecedented innovation in the field of consumption and dressmaking, however, the nineteenth century was equally preoccupied with values of the past and moral certainties. ${ }^{9}$

This is why, even though the second part of the nineteenth century is known as the century of the bourgeoisie (especially in England, France, and Germany) in the Central European countries and particularly in Hungary the social dynamic took a different trajectory. The social-political life was still very much organized around and directed by the estates, in which the aristocracy had a central role. As in Poland, the Hungarian nobility made up more than 5 per cent of the population and held 50 per cent of the land ${ }^{10}$. Although change was inevitable, until the turn of the century the political decisions were mostly made by the aristocracy. The political role put on them special responsibility, meaning they had to follow symbolic rituals, their political capital was shown by their consumption and behaviour. The so 
called 'aristocratic life' was marked by a sense of social duty, what Miss Stevens mentioned repeatedly in her letters as 'noblesse oblige.' It was an obligation to host balls and receptions, to build luxurious houses in the city. Before turning to the analysis of the 'díszmagyar' and its political character it is important to sketch out the urban historical setting where the performance took place.

Similarly to other European cities, Budapest went through a remarkable urban development in the second part of the nineteenth century. It was the fastest growing city in Europe, reaching one million by the First World War. ${ }^{11}$ An important date in the history of the city was 1873 when Budapest was officially born from the unification of Buda, Pest and Óbuda. Prior to 1873 these three settlements had separate administration. Buda was a royal free town with the castle and medieval street system surrounded by hills and vineyards. Pest had been the economic centre of the country since the Napoleonic times, but in spite of this, it resembled more a market place than a modern trade centre. The most important factor in the modernization of Buda and Pest, from both symbolic and urban point of view, was the construction of the Chain bridge over the Danube in 1849. The Chain bridge connected not only the two sides of the city, but the eastern and western part of the country as well. As a result, Buda and Pest became the commercial and administrative centre of the country. It also became the centre of the national economy thanks to economic and political developments in the Reform Era. ${ }^{12}$ Naturally, the role of the trade was significant in the circulation of luxury goods as well.

Population growth was the most pronounced in the 1850 s, and by the late 1860 s every third inhabitant was a newcomer. ${ }^{13}$ The developing city was attracting not just people from rural areas or foreigners searching for employment, but the aristocracy as well. Due to the seasonal character of their life, the aristocracy still divided their time between Pest, a country house, a hunting lodge somewhere in the mountains, Karlsbad or some other spa resort. From the 1860s on however, more and more time was spent in Pest, especially after the 1867 Austro-Hungarian 
Compromise when it became the chosen location for numerous social and political events. This put a mark on the capitalist development of the city and contributed largely to the restructuring of the urban space and urban economy. As the location of the new capital, it became more and more common for the aristocracy to stay in Budapest for longer periods. Count István Széchenyi, a prominent reform figure, already had a plan linking the development of the city with the settling of the aristocracy. He thought that if the aristocratic families would build palaces and move to Pest the manufacture, commerce and trade would get a boost as their consumption would improve the urban economy ${ }^{14}$. Széchenyi's initiative was echoed even three decades later by the press when reacting to the constructions initiated by Count György Festetics, Count Lajos Károlyi and Count Pál Esterházy. One contemporary newspaper account praised the palaces and the initiative saying that "it is a generous gesture from the aristocracy that they devote part of their wealth to the beautification of the city and thus to the dissemination of taste"; the journalist also expressed his hope that once the palaces will be furnished with all the necessary equipment, the family would settle permanently and have a positive effect not only on the social, but also on the literary and artistic life, and on the industrial development of the city." ${ }^{\prime 15}$ The aristocracy's agency in the transformation of the urban landscape, especially the construction of the so called Palace District helped the development of the service sector, attracted craftsmen, shaped the urban landscape, and most importantly, influenced the development of the city infrastructure. Furthermore, the imperial court was staying in the city from time to time, which had an enormous impact on the economy of the city. Buda-Pest, the newly emerging capital city next to Vienna, became a stage for official court ceremonies and festivities, for various social events for which the 'díszmagyar' was the costume of the Hungarian aristocracy.

\section{'Noblesse oblige': the 'díszmagyar' as a necessary luxury}


The following is an analysis of the 'díszmagyar' as a manifestation of the obligatory luxury or functional luxury as was suggested by Berry and presented in the introduction. Given the premise that consumption is an exercise in identity construction, this section will explore the ways in which garments enabled the aristocrats to construct social identities. ${ }^{16}$ Mary Stevens' comments about the everyday activities of the Andrássy family reveal nuances in the connection between the concept of luxury and social representation. Mary repeatedly commented on balls, dinners, and afternoon tea as a noble obligation. Similarly, Countess Maria Festetics notes in her diary that Count Gyula Andrássy took part in political life motivated by a feeling of duty towards his country and emperor, and he was not getting any material reward for it. ${ }^{17} \mathrm{He}$ and his wife were the centre of society, especially after the Austro-Hungarian Compromise. The court ball, held every two or three years in Buda, was where the Hungarian peerage appeared in their best. These balls were important for the urban economy from confectioneries to tailors and dressmakers.

The Hungarian gala dress, the 'díszmagyar' was the most luxurious; it was perceived by the tailors as a masterpiece. It is described in 1866 by Mary:

The elegance here is really wonderful, I never saw anything to equal it. You asked me about costumes. I think I have told you about the Hungarian ones. The court dress must be most rich, especially for gentlemen. They wear suits with tight trousers of dark velvet embroidered with gold; a small Spanish cloak over one shoulder, also of velvet, trimmed with fur and claps of gold and precious stones; small toques of velvet with plumes fastened in aigrettes of diamonds and other gems. The ladies wear long trained dresses of all sorts of rich stuff, the body laced across like a stomacher; a wide apron of beautiful lace; white lace short sleeves to match. ${ }^{18}$

What Mary calls a Spanish cloak on one shoulder is nothing else than the so called 'mente', a special overcoat or pelisse, worn as a sleeveless cloak which is the mandatory component of 
the 'díszmagyar'. Under it, over the shirt the men wore the 'attila' which was a waist-cut 'dolman'19 with a stand-up collar decorated with metal lace cording and trimming. These were made of velvet or silk and worn with tight trousers and long embroidered boots. In the case of the ladies the skirt was following the form of the European trends, having a lace apron, but the upper part was also composed of a white shirt and a corded, laced bodice, with similar elements as the men's 'attila'.

This type of dress was designed by Ádám Kostyál in the late 1820s and became popular in the 1830 coronation of Ferdinand $\mathrm{V}^{20}$ Ádám Kostyál was a tailor who made costumes for the theatre as well. ${ }^{21}$ In the patriotic atmosphere of Romanticism he designed the Hungarian gala dress inspired by historical dress, especially by the seventeenth century outfit with a 'dolmány' and 'mente'. This type of gala dress became popular because it helped Hungarians to distinguish themselves in a visible way from the Austrians, and because the cut of the 'dolmány' followed the line of European fashion. ${ }^{22}$ Similarly cut attire was worn by lesser nobles as well, but the richly decorated gala dress reserved as reamained the hallmark of aristocracy; the bourgeoisie was not advised to wear it. ${ }^{23}$ Worn only by the aristocracy, and constructed from exquisite textiles with lavish decorations such as family jewels, buttons and silver or gold cording, this form of 'díszmagyar' clearly fell into the category of luxury. ${ }^{24}$ It not only showed the wealth and power of the wearer, it also communicated the separate social and national identity of the Hungarian aristocracy vis-a-vis the Habsburg court. Although, there are arguments for the 'díszmagyar' as a symbol of wealth regardless of national origin, the elaborately embellished versions made a clear distinction between aristocracy and lesser nobles of various nationalities within the Monarchy. ${ }^{25}$ Thus, by the fin-de-siècle this type of clothing became an evident signifier of status. In the 1830s the 'díszmagyar' was used widely, but in the dualist period it was kept for state occasions, weddings and other festive occasions which is discussed further on in this paper. 
Another aspect of the 'díszmagyar' in the context of luxury is the combination of old and new. Depending on the context, luxury can be viewed as something old, antique; or something which follows the latest trend, something innovative. The gala dress was combining the two by taking advantage of a new European style cut, making it easier to fit in the court, but essentially referring back to a traditional Hungarian item of clothing. This combination also reflects the dual identity of the Hungarian aristocracy. Culturally they were part of the Viennese court society, part of the aristocracy of a multinational empire, but historically they were members of the Hungarian nation. ${ }^{26}$ Although Budapest was on the way to becoming a modern metropolis, Vienna remained the place for the "social theatre". The dress became very popular in the 1860 s and in the wardrobe of the Hungarian aristocracy it essentially replaced the French or German style dress. As the various state and court events were covered by the press, the 'díszmagyar' made its way to not only into Hungarian newspapers, but into Viennese and the French Journal de Dames as well. The first international success of the dress was in 1829 in Paris, when a design done by Kostyál was worn at a ball by Count Rudolf Apponyi. ${ }^{27}$ The 'díszmagyar' received publicity in the contemporary fashion press and its various elements, especially the cording and the cut of the 'mente', were introduced in the latest fashion. Viennese fashion magazines regularly chose Hungarian aristocratic ladies for their front page, further enhancing the spread of Hungarian fashion. ${ }^{28}$ However, this did not dilute the exclusive aspect of the dress, since only particular elements were taken over. The essence of the 'díszmagyar' is complex. In keeping with Berry's theory of categorical continuity with substantive discontinuity it was a luxury item that contained decoration or fabric which came from the family's treasury, but applied on or combined with a new dress. In this way the garment was also historicized and transformed into a traditional marker of ancestry, past glory and legitimacy in the contemporary social system.

Countess Katinka Andrássy was one of the most frequently mentioned ladies in the press, second only to the shy Empress Elisabeth. Not only was she beautiful, she was also the wife of 
Gyula Andrássy, the first prime-minister of the Austro-Hungarian Monarchy. Her social position required her to pay special attention to her outfits, although as we know from the letters of Mary Stevens, she was not very much keen on ceremonial dresses and spectacle. Katinka rather preferred to stay at home and read. Mary's description of the dress the countess wore at the court presentation in Buda in 1865 explains the enthusiasm of the press:

"There were 90 ladies in fullest court dress. My Countess looked most lovely, she had on a white moiré-antique dress trimmed with a superb black lace, a train four yards long (that was the regulation length), a black lace apron (that belongs to the costume), the body made rather like a stomacher in front, laced across and across, with large claps of diamonds down to the waist; a coronet of diamonds with three magnificent emeralds, pendants, ditto earrings, ditto necklace and bracelet; from one side of the coronet fell the black veil shading with one end the right shoulder, the other falling almost to the feet behind; she looked lovely, so glittering with diamonds that she was quite dazzling."29

The exclusivity and richness was not unlike that of her husband, Gyula Andrássy:

"Our Count was in maroon velvet with a beautiful belt of gold, pearls and emeralds and other precious stones, his cap was decorated with a beautiful clasp matching his belt and an eagle's feather. He looked very well though his dress is not quite new, as of course lately there has been no necessity for court dress; he is going to get one of black velvet." ${ }^{30}$

The dresses of the male aristocrats was as richly decorated as that of the ladies,' if not more so. The gender division in the public performance of the Hungarian aristocracy was less pronounced and both (male and female) participated equally in the 'social theatre' with the 'diszmagyar' as exclusive accessories. The Coronation of Franz Joseph with the Hungarian crown on the $8^{\text {th }}$ of June, 1867 marked the establishment of the Austro-Hungarian Monarchy providing an important occasion for the aristocracy to wear the family armour and jewels. They marched through the city with pride, imagining themselves copies of their glorious ancestors. 
The political character of the 'díszmagyar' was evident, since throughout the so called neoabsolutist period (after the defeat of the 1848 revolution) everything that had reference to the national character was banned by the court. ${ }^{31}$ On the top of the list was the Hungarian gala dress. It was especially important for the aristocracy to pick up on these elements and refer back to history as a signifier of their political success. Mary was astonished by the sight of the coronation procession:

"The magnates, with more sense than I should have given them credit for, ranged and marshalled themselves just under our balcony, [...] There was scarcely one who had not something distinguished in the shape of jewels, furs, etc. The Baron Wenckheim has a magnificent ornament shaped like a plume from which hung several immense emeralds; the trappings and saddle-cloth of the Prince Esterhazy were one mass of precious stones; and then their costumes! There was cloth of gold and of silver, velvet of every shade and colour."32

For this occasion Count Andrássy wore a new 'díszmagyar' with a set of jewels adorned with gems from the family heirloom: goldsmith's buttons of three different sizes (the mente/pelisse had the largest, medium size one on the 'attila' and the smallest were decorating the vent of the sleeves and the side of the pelisse), a goldsmith's chain fastening the 'mente' decorated with an ivory portrait of Medusa, a belt, a sword-ling, spurs and agraffe. ${ }^{33}$ Ludwig Ritter von Przibram compared the magnificent sight of the horse tack, jewelled swords and old guns with turquoise, ruby and pearl with Eastern pomp. Characterizing the whole scene, however, he wrote that the procession taken as a whole seemed rather like a muster of feudal-aristocrats: "Seeing all the well-dressed barons and flagmen of the country, escorted by a silent humility of their armed henchmen and vassals, one really felt to be again in the Middle Ages." ${ }^{34}$ The analogy to the eastern pomp appears because indeed the male gala dress with its fur trimmed velvet 'mente', colourful silk 'dolmány' and tight corded boot trousers reminded the onlookers of Oriental traditions. Historicizing as well, the ladies' dresses preserved the laced bodice and aproned skirt 
of the sixteenth and seventeenth centuries. The anachronistic character of the gala dress was also noted in 1891 by two English ladies who travelled through Austro-Hungary. One of their hosts, "Count F." impressed them with his 'díszmagyar':

"He seemed to have gained several inches in the dress, and looked like some majestic creature who had suddenly stepped from the middle ages; [...] The dress seemed to have called to life all the pride and fire latent in his easy-going face, to have suddenly aroused the reverse side of the Magyars. [...] The form never changes but the colour and jewels vary with the family. I can hardly imagine a finer sight than a regiment of nobles, mounted on horses draped in their respective colours, riding along in the sunlight; and such a spectacle, $[\ldots]$ is still to be seen on royal occasions." ${ }^{35}$

This passage not only resonates with the theatrical aspect in the foreign accounts above, it also gives an insight into the role, significance of the 'díszmagyar' for the aristocracy in their identity construction and preservation process. As a hallmark of continuity, this luxurious and unique ceremonial clothing was kept and handed down to generations. This is the reason why we know about the silk and velvet festive dress of Countess Stefánia Majláth, né Pradau who wore the gown for the 1867 coronation and with little modification for the 1896 millennial festivities. In 1916 her daughter-in-law wore the same outfit in at the coronation of Charles IV. ${ }^{36}$

By the nineteenth century throughout Europe the male outfit became simple, less colourful and with fewer decorations, yet the lady's dresses compensated for this. ${ }^{37}$ The latter became the outlet for representing the social status of the family. Especially in the 1860 s, with the introduction of the crinoline, skirts became bigger, lace and flounces covered the ladies, more precious stones were applied and the colour scheme enriched. ${ }^{38}$ While in the French, English or German courts men wore black frock tails for official events, in Hungary they had various types of colourful velvet and silk garments. Especially on state occasions, both men and women wore very colourful clothes, with various precious stones and pearls applied on them or worn on their headdresses and hats. In this way the representational role of the women was shared by 
the men as well, through the wearing of similar exclusive textiles and rich decorations. The Swiss ambassador noted about the 1867 coronation that it rather looked like a carnivalesque procession with all the vivid colours worn by both men and women. In comparison with other Western European men's outfit which were only black and white, with the use of colour restricted only to the bowtie or waistcoat, the Hungarian aristocrats in their colourful attire seemed entirely anachronistic. ${ }^{39}$ The use of old fashioned dress was a deliberate choice not because they were ignorant of Parisian or London fashion trends, but rather because of the special significance of the outfits for their national and political cause.

\section{'Tailor magnates' in the city}

In spite of the fact that the city was growing and numerous types of goods were accessible, the goods used in creating the 'diszmagyar' were often more expensive or were not of a high enough quality. Mary was constantly complaining about the prices of clothing and textiles in general: "My silk jacket is sadly worn out, [...] and I do so dread buying one it will, I fear, cost so much. I thought, if I am obliged to purchase, of begging Aunt Amalie to get me something very nice in Vienna where they are not too high a price. ${ }^{40}$ The reflection on housing is not much different and the prices compared to England are much higher, but the living conditions are worse. Food and primary materials were widely available; however, finer products and luxury could be had in Vienna or other European cities. According to Mary, only the gloves seem to be of better quality and cheaper than in London. ${ }^{41}$ Not surprisingly the Countess bought the furniture for the Sándor Palace, (the official residence of the prime-minister) in Vienna. ${ }^{42}$ In spite of the scarcity and low quality of available services, organizing dinners and other events by the aristocracy was a social obligation and this started to have a growing impact on the economy of the city. The great scale of these events reminds us of the dream of Széchenyi about the beneficial aspects of aristocratic consumption on the urban economy. 
"There is going to be a gigantic soirée tonight, nearly 700 people are to be here [...] Why, the confectioner alone who had the refreshments to provide must have at least 700 florins; and then the wax candles for all those large rooms, and all the numerous other things - it must be a dreadful expense. But nobility obliges, you know, and the Count must pay the price of his grandeur. ${ }^{43}$

The phrase 'noblesse oblige' appears several times in Mary's letters as referring to the justification of all the spending and luxury. All these activities, just like the festive garments are players in their social theatre in the city. Even though the Countess, a person with simple taste was not much fond of balls and ceremonies, being the wife of the prime-minister forced her to fulfil certain social obligations, especially in the city. On one occasion Mary was witness to the Countess voicing her opinion and she comments:

"I like her much, [...] (she is) so straight forward, honourable and sincere - and not the slightest pride or vanity about her, indeed if anything she has too little vanity; the Count often scolds her when she neglects to dress for dinner and she always says, 'provided one be clean and neat what does it signify in the country?" ${ }^{44}$

If we accept that goods tell as much information about status as about personality, then the above quotation underlines even more the prop character of the festive dresses. They also support the rural and urban divide in the choice of clothing; with a preference for sophistication and quality in the latter. In the city a lady could not appear twice in the same dress, they either modified the previous, or ordered a new one. All this made a substantial impact on the economy of the city, and more precisely on the dress making industry.

In spite of the rapid modernization the industries were organized into guilds until the late nineteenth century. The tailors' guild was abolished only in 1872, making place for the Trade Association in $1885 .{ }^{45}$ In 1803 the guild of Hungarian tailors in Pest making Hungarian clothing had 33 members; the German guild which was specialized in European fashion had 79 
members. The numbers change radically by 1827 , when the first one had 32 members and the latter $207 .{ }^{46}$ Textile factories however, were producing low quality fabric, not suitable for the festive dresses. The Valero silk factory, established in 1839, functioned only until 1849 in spite of the fact that it was copying Parisian models in better quality fabric. The period of the Protective Association ${ }^{47}$ was the only time when the locally produced textiles were in use. One noted example was the ball of 1845 where ladies were required to make their dresses from blue-dyed calico favoured by the peasantry. ${ }^{48}$ This general development, or "non-development" of the textile industry, however is only indirectly connected to the consumption of the aristocracy who were buying most of their clothing abroad. Because they could not find goods satisfying their needs in Pest-Buda, London was the preferred shopping venue for the men while Paris or Vienna for the ladies. Already in the 1820s Széchenyi was wearing the English dress, which was associated with good quality textiles, practicality and comfort. The 'Oscar Wilde dandyism' and especially sportswear became very popular in the 1850-60, because the masculine ideal had become the English gentleman. The centre of fashion for the ladies between 1814 and 1830s was Vienna, but after 1850 they shopped in or ordered from Paris. In 1869 , before the social season Katinka Andrássy ordered her dresses from Paris:

"The Countess has had a heap of French letters that of course were shuffled on to my unfortunate shoulders, and I had to go to Pesth to buy French money to send to a woman in Paris who is making her a dress for a costume ball in Vienna; she is going there for a week or two for the Court balls. She will be the Sea, and very elegant, the dress will cost 600 francs." 49

Even Mary bought a dress through the shopping network of the aristocracy:

"I have just bought a dress for four florins - one from Paris and such a nice one. It happened that the Pejacsovichs were sending to Paris for some dresses and their governess sent for one and did not like it when it arrived because it was a washing material, so I took it off her hands. And I like it so much, and of course I can get it washed as often as I like here." ${ }^{20}$ 
Although most ball gowns and other exclusive garments were made abroad, the gala Hungarian costume was a specialty of Pest tailors. In the context of urban economy, especially linked to the tailors' and dress-makers' association - the 'díszmagyar' had a special role. This was the garment which was made by local tailors, but from imported materials. In the 1840-50s three names were associated with making them: Ádám Kostyál, the inventor of the 'díszmagyar', Vencel Klasszy and Gáspár Tóth. ${ }^{51}$ After 1830 more and more tailors moved to Pest from Vienna. In spite of a weak textile industry, a rise in the general demand for dressmaking, caused by an increase in population, brought an increased number of tailors, especially those from Germany.

However, it was not just any tailor who could make the 'díszmagyar' or make festive dresses for the aristocracy. There was a separate group of tailors who produced clothing exclusively for the aristocracy, the so-called 'magnate tailors.' These tailors did not advertise in newspapers, they served an exclusively aristocratic clientele on the basis of recommendations. Countess Katinka Károlyi, - the granddaughter of Katinka Andrássy - wrote in her memoirs that during the ball season the doorknob was given from tailor to seamstress without interruption. There was a long queue on the corridor from the representatives of the fashion saloons who lined up with boxes and models. When the tailor Herr König was announced, she as a child always thought that Emperor Franz Joseph was arriving, because everybody was behaving in an elevated way ${ }^{52}$ This example illustrates the high prestige of the 'magnate tailors'. Alter \& Kiss, Monaszterly \& Kuzmik and later Girardi were the most well known female dress makers, producing both European style festive dresses and 'díszmagyar' as well. For men, János Schäffer was not only considered a star tailor, but a fashion dictator as well. In his size-book all the aristocratic names appear, earning him the honorary title of the 'Permanent Tailor of Magnates'.53

By the turn of the century thanks to the development of the industry and manufacture and in general to Budapest becoming a European metropolis, a proliferation of luxury tailors can 
be observed. In addition, numerous Viennese companies moved or opened agencies and warehouses in the city. Skriván hatmaker, Tiller uniform and gala dress-maker, Neumann's shop for gentlemen were all originally in Vienna, but transferred altogether to Pest during this period. Rothberger, Ebenstein and Rosenthal although opening stores in Pest, kept their head office in Vienna, and shipped ready-made clothes to the city. ${ }^{54}$ As the fashion of the 'díszmagyar' was spreading all over to Paris thanks to the fashion magazines, the tailors in Vienna realized the potential in learning the cut of the gala dress and began producing it. Following this trend, Empress Elisabeth's Hungarian dress for the Millennial celebrations in 1896 was made by the Viennese Breyer company. More aristocratic ladies commissioned their gala dresses from Viennese companies than men; the 'díszmagyar' of the latter was almost exclusively made in Budapest. This is how we know about the Laufer Company who made the dresses of Countess Eszterházy-Andrássy, although most others were made by the Spitzer Fashion House including those for Lady Mary-Victoria Douglas-Hamilton, wife of Count Tasziló Festetics and for the wife of Count Géza Andrássy. An interesting and significant detail regarding the 'díszmagyar' is the fact that the Spitzer Fashion House at the 1898 fashion exhibition was represented with an "ungarische Nationalcostüm."55

The group of Hungarian aristocrats dressed in their red, green, blue, etc., coloured 'díszmagyar' at the 1989 funeral of Zita, the last Hungarian Queen, was a curious sight. As in other European countries, the colour of the mourning was black, yet for this occasion the Hungarian aristocrats chose to make a symbolic gesture by putting on their festive Hungarian gala dress in honour of the queen, in spite of its anachronistic and unsuitable look. This act underlines the symbolic importance and the continuity of the 'díszmagyar' for their public and group identity.

\section{Conclusions}


This chapter aimed at explaining the development and use of the 'díszmagyar' by the aristocracy for ideological purposes in the context of nineteenth century urban development of Budapest. The case of the Andrássy family offers fruitful material for analyzing the subtle nuances of status and the organization of shopping in the city. The premise being that the 'díszmagyar' was a luxurious item with a complex symbolic value, with layers of meaning, combining family history with contemporary aspirations for power. Similarly to other luxury goods, the 'díszmagyar' was used only by the top layer of the society, - the aristocracy.

The establishment of the Austro-Hungarian Monarchy transformed Budapest into a metropolis. For the rural masses this meant employment opportunity, while for the aristocracy it became a new scene for politics and representation. This chapter has built on the concept of social theatre in which the use of distinctive external characteristics was strongly connected to preserving social hierarchies. In this framework the 'diszmagyar' was a tool in the urban performance of the aristocracy.

The insistence of the aristocracy on the use of the 'diszmagyar' made an impact on the dress making industry of Budapest by driving the formation of the 'magnate tailors.' However, this impact only had a limited effect in general on the over-all urban economy, because the Hungarian textile industry was incapable of producing the fine quality fabrics required for these exclusive garments. Thus, the tailors or the aristocracy had to buy them from abroad. The analysis has also showed that although most of the Hungarian festive dresses were made by local tailors, the ladies' dress were often produced in Vienna.

The investigation has revealed interesting results about the relation between gender and luxury in comparison to other European societies. While in other European courts the black and white outfit was considered the model for the modern men, the Hungarian noble men wore red, green, blue, purple, yellow etc., colour outfits for festive occasions. The explanation for this can be found in the historicist character of the 'díszmagyar' and in the different understanding of what was considered masculine and powerful. While on festive and political occasions the 
Hungarian aristocrats wore their ancestor's colourful garments, for everyday life, and especially for sport, they followed the English gentlemen's model. This aspect connects to the question of the circulation of goods and demonstrates that they relied on the international luxury market, for either ordering or direct shopping. While the men preferred London, the ladies purchased their exclusive garments in Vienna and from the 1860s in Paris.

Overall, this chapter has contributed to the understanding of Christopher Berry's theoretical frame of analyzing luxury as a categorical continuity with substantive discontinuity. By looking at the festive outfits of Hungarian aristocrats as a tool in their urban performance we have highlighted the dual character of their identity. Combining the 'old' and 'new,' the traditional and the modern, the public activity of the aristocracy contributed to the forces of development of nineteenth century modernity, which was built on this dichotomy.

${ }^{1}$ Christopher J. Berry, The idea of luxury: a conceptual and historical investigation (Cambridge: Cambridge University Press, 1994), 5.

${ }^{2}$ Ibid, 231-232.

${ }^{3}$ Ibid, 242.

4 'Luxury Trades' in Joel Mokyr (ed.), The Oxford Encyclopedia of Economic History (Oxford : Oxford University Press, 2003). 401.

${ }^{5}$ Maxine Berg, 'Luxury, the Luxury Trade, and Industrial Growth' in The Oxford Handbook of the History of Consumption (Oxford University Press, 2012), 179.

${ }^{6}$ Fernand Braudel, The Structures of Everyday Life: The Limits of the Possible, (Los Angeles: University of California Press, 1981), 184.

${ }^{7}$ A selection of her letters was published under the title Letters from Hungary 1864-1869: Written by Mary Elizabeth Stevens to Her Mother and Sister (London: DRP, 1999). A Hungarian translation, including a few more letters than the original was published in András Cieger (ed.), Vera Bánki (transl.), Levelek az Andrássy házból: egy angol nevelőnő levelei, 1864-1869 (Letters From the Andrássy House: The letters of an English governess, 18641869)(Budapest: General Press, 2007). A presentation of the source in András Cieger, 'We are now the first people in Hungary'. Count Andrássy's Family and Friends through the Eyes of an English Governess,' New Hungarian Quarterly, 3(2008) 133-142. I would like to take this opportunity to thank András Cieger for giving me the original publication of the letters and his valuable advice. In this paper I will refer to the English publication.

${ }^{8}$ Tibor Frank, Picturing Austria-Hungary: the British perception of the Habsburg Monarchy, 1865-1870, (Boulder, Colo.: Social Science Monographs, 2005). 178.

${ }^{9}$ Christopher Breward, The Culture of Fashion (Manchester: Manchester University Press, 1995), 176-178. 
${ }^{10}$ László Péter, 'The Aristocracy, the Gentry and their Parliamentary Tradition in NineteenthCentury Hungary' The Slavonic and East European Review 1 (1992): 79.; Iván T. Berend and György Ránki, Hungary, a Century of Economic Development (Newton Abbot: David \& Charles, 1974), 41-42; Gábor Gyáni and György Kövér, Magyarország társadalomtörténete a reformkortól a II. világháborúig (The social history of Hungary from the Age of Reforms until World War II.)(Budapest: Osiris, 2006), 118.

${ }^{11}$ András Gerö, Poór János (eds.) Budapest: A history from its Beginnings to 1998. (New York: Columbia University Press, 1997). 3-4

${ }^{12}$ László Csorba, 'Transition from Pest-Buda to Budapest, 1815-1873' in Budapest, a history from its beginnings until 1998. 84.

${ }^{13}$ lbid, 71

${ }^{14}$ István Széchenyi, Buda-pesti por és sár, (Dust and Mud in Buda-Pest) ed. Ervin Fenyő (Budapest: Balassi, 1995), 5, 16. Written between 1837-40, first published in 1866.

${ }^{15}$ Vasárnapi Újság, 1864. 345. Similar ideas were expressed in Az Ország Tükre, 1863, 402.

${ }^{16}$ Ann Bermingham and John Brewer, The consumption of culture, 1600-1800: image, object, text (London: Routledge, 1995), 15.

17 Mária Festetics, Egy udvarhölgy naplójából: Festetics Mária grófnő, udvarhölgy naplójának Budán és Gödöllön papírra vetett részei (From the Diary of a Lad in Waiting:Sections from the diary of Countess Mária Festetics written in Buda and Gödöllő)(Gödöllő: Gödöllő Királyi Kastély Múzeum, 2009) 71. See also Max Weber, 'Politics as Vocation' in The Vocation Lectures, 32-

${ }^{18}$ Stevens, Letters from Hungary, 55.

${ }^{19}$ The word 'dolmány' is coming from the Turkish 'doloman' and it is a front-buttoned coat, whose origin goes back to the caftan.

${ }^{20}$ Katalin F. Dózsa, 'Court and City Costume in the 18th to 20th Centuries' in Historic Costume from Budapest, Exhibition catalogue (Manchester: Whitworth Art Gallery, 1979), 17.

${ }^{21}$ Katalin F. Dózsa (ed.), 1116 Years of Hungarian Fashion (Budapest: Absolut Media Zrt, 2012), 83.

${ }^{22}$ Anikó Lukács, 'Nemzeti divat a pesti magyar nyelvü sajtóban az 1850-es, 60-as években' (National Fashion in the Hungarian Press of the 1850-60s ) in Nemzeti látószögek a 19. századi Magyarországon (Budapest: Atelier, 2010), 277-283.

${ }^{23}$ Katalin F. Dózsa, 'A rendi nemzettudat szimbóluma, a díszmagyar.' (The Díszmagyar: Symbol of national consciousness of the estates) in Tamás Hofer ed., Magyarok Kelet és Nyugat között (Budapest: Néprajzi Múzeum, 1996) 161.

${ }^{24}$ Lukács, 'Nemzeti divat...' 284, 297-298.

${ }^{25}$ Ibid. 161; Anikó Lukács, 'Átöltözések. A 19. századi magyar nemzeti divat emlékiratok és naplók türkében' (Changing clothes. Hungarian national fashion in the nineteenth century in the mirror of diaries and memoirs) Aetas 3(2008), 46-64.

${ }^{26}$ Hungarian "nation" until the First World War basically meant the nobility. This is due to the peculiar composition of the Hungarian society and to the fact that the initiators of modernization were the nobles.

${ }^{27}$ Katalin F. Dózsa (ed.), 1116 Years of... 82.

${ }^{28}$ Katalin F. Dózsa, 'Osztrák-magyar kapcsolatok és kölcsönhatások a divat területén 1850 és 1916 közöt' (Austro-Hungarian Relations and Interferences in the Field of Fashion between 1850 and 1916) Folia Historica 5(1977),184.

${ }^{29}$ Stevens, Letters from Hungary, 108. 
${ }^{30}$ Ibid, 106.

${ }^{31}$ Robert Nemes, 'The Politics of the Dance Floor: Culture and Civil Society in NineteenthCentury Hungary,' Slavic Review, 4(2001): 802-823.

${ }^{32}$ Ibid, 124-125.

${ }^{33}$ Katalin F. Dózsa,"How the Hungarian National Costume Evolved" in The Imperial Style: Fashion of the Hapsburg Era (New York: The Metropolitan Museum of Arts, 1980), 74-99.

${ }^{34}$ Ludwig Ritter von Przibram: Erinerung eines alten Österreichers, Stuttgart, 1910. I. 187. Quoted in Brigitte Hamann, Erzsébet királyné (Budapest: Európa, 2012) 284.

${ }_{35}$ Margaret Fletcher, Sketches of Life and Character in Hungary, (London: Swan Sonnenschein \& Co., 1892), 71-72.

${ }^{36} \mathrm{~F}$. Dózsa (ed.), 1116 Years of..., 117.

${ }^{37}$ Christopher Breward, The Hidden Consumer: Masculinities, Fashion and City Life 1860-

1914 (London: Manchester University Press, 1999) 24-27.

${ }^{38}$ Cally Blackman, 100 Years of Fashion Illustration (London: Laurence King Publishing, 2007), 8.

${ }^{39}$ Quoted in Katalin F. Dózsa, 'Királynék díszmagyarban. Magyar női díszruhák' (Queens in 'Díszmagyar.' Ladies' Hungarian Festive Dresses) Rubicon, 6(1990). http://www.rubicon.hu/magyar/oldalak/kiralynek diszmagyarban magyar noi diszruhak/ last accessed 25. 10. 2013.

${ }^{40}$ Stevens, Letters from Hungary, 171

41 Ibid, 188.

42 Ibid. 119

${ }^{43}$ lbid, 165-166.

${ }^{44}$ Ibid, 96.

${ }^{45}$ Katalin Dózsa, 'A szabóipar helyzete a századfordulón' (The Situation of the Tailors at the Turn of the Century) in VII. Kézmüvesipartörténeti Szimpózium (Budapest: MTA, 1991), 55.

${ }^{46}$ F. Dózsa (ed.), 1116 Years of..., 74.

${ }^{47}$ The Protective Association was founded in 1844 as a union whose members signed not to buy foreign goods if they exist in Hungary and to support local industry. However in their 6 year of existence only until 1846 were working actively involved in their aim, 1846 being the best year.

${ }^{48}$ Terézia Pulszky, Egy magyar hölgy emlékiratai (Memoirs of a Hungarian Lady)(Budapest: Magvetö, 1986), 10.

${ }^{49}$ Stevens, Letters from Hungary, 200.

${ }^{50}$ Ibid, 174.

${ }^{51}$ Lilla Tompos, A díszmagyar: a magyar díszöltözet története (The Gala Hungarian: History of the Hungarian festive dress)(Budapest: M. Mercurius, 2005), 113-115.

${ }^{52}$ Katinka Károlyi, Együtt a forradalommal (Together with the Revolution) (Budapest: Európa Könyvkiadó, 2011, (1967)) 19.

${ }^{53}$ Szabó Hírlap 1910, 23-24, 64. Quoted in Tompos, 2005, 116.

${ }^{54}$ F. Dózsa, 'Osztrák-magyar kapcsolatok...', 178

${ }^{55}$ Ibid, 186-187. 